\title{
ORGANIC CARBON IN SHALLOW SUBTERRANEAN HABITATS
}

\section{ORGANSKI OGLJIK V PLITVIH PODZEMELJSKIH HABITATIH}

\author{
Tanja PIPAN ${ }^{1} \&$ David C. CULVER ${ }^{2}$
}

\begin{abstract}
UDC 551.44:546.26

Tanja Pipan \& David C. Culver: Organic carbon in shallow subterranean habitats

Organic carbon is likely to be a limiting factor in shallow subterranean habitats (SSHs). Data on dissolved organic carbon (DOC) in three SSHs are reviewed: (1) hypotelminorheic and associated seepage springs (Nanos Mountain, Slovenia), (2) hyporheic zones (Rhône River, France and seepage streams on Nanos Mountain, Slovenia), and (3) epikarst (China, Slovenia, and USA). Hypotelminorheic habitats are superficial groundwater sites less than $1 \mathrm{~m}$ below the surface that exit from seepage springs. Hyporheic habitats are the underflow of streams and rivers. Epikarst is the uppermost zone of karst with extensive small cavities and channels. Nanos hypotelminorheic sites that harbored stygobiotic species had organic carbon values averaging $3.4 \mathrm{mg} \mathrm{C} \mathrm{L}^{-1}$, and temporal variability was high. For hypoheic sites in the Rhône River basin and on Nanos Mountain, mean values ranged from 1.4 to $3.5 \mathrm{mg} \mathrm{C} \mathrm{L}^{-1}$. In the more extensively studied Rhône River basin sites, temporal variability was low. Epikarst DOC ranged from 0.70 to $1.10 \mathrm{mg} \mathrm{C} \mathrm{L}^{-1}$ in three caves in China (Shihua Cave), Slovenia (Postojna Planina Cave System) and United States (Organ Cave, West Virginia). These results suggest that organic carbon in aquatic SSHs is lowest in epikarst.

Keywords: dissolved organic carbon, epikarst, hyporheic, hypotelminorheic, seepage spring.
\end{abstract}

Izvleček

Tanja Pipan \& David C. Culver: Organski ogljik $v$ plitvih podzemeljskih habitatih

Organski ogljik je najverjetneje omejujoči dejavnik v plitvih podzemeljskih habitatih (SSH). Analizirali smo podatke o raztopljenem organskem ogljiku (DOC) v treh SSH: (1) hipotelminorejik z mezišči (Nanos, Slovenija), (2) hiporejik (reka Rona, Francija in manjši potočki na vznožju Nanosa), ter (3) epikras (Kitajska, Slovenija in ZDA). Hipotelminorejični habitati so mesta s podzemeljsko vodo v globini do enega metra, ki primezi na površje iz drobnih izvirov - mezišč. Hiporejični habitati so podzemeljski tokovi potokov in rek. Epikras je predel tik pod površjem krasa, prepreden s številnimi majhnimi votlinami in kanali. Povprečne vrednosti organskega ogljika $\mathrm{v}$ hipotelminorejičnih habitatih s stigobiontskimi vrstami na Nanosu so znašale $3,4 \mathrm{mg} \mathrm{C} \mathrm{L}^{-1}$ in so $\mathrm{v}$ različnih obdobjih močno nihale. $\mathrm{V}$ hiporejiku Rone in potočkov na Nanosu so srednje vrednosti znašale med 1,4 in $3,5 \mathrm{mg} \mathrm{C} \mathrm{L}^{-1}$. V dobro proučenem porečju Rone je bila časovna variabilnost majhna. Vrednosti DOC v epikrasu v treh jamah se gibljejo med 0,70 do $1,10 \mathrm{mg} \mathrm{C} \mathrm{L}^{-1}$ (jama Shihua na Kitajskem, Postojnsko-Planinski jamski sistem in jama Organ v Zahodni Virginiji, ZDA). Iz rezultatov sklepamo, da so vrednosti organskega ogljika v vodnih SSH najnižje v epikrasu.

Ključne besede: raztopljeni organski ogljik, epikras, hiporejik, hipotelminorejik, mezišče.

\section{INTRODUCTION}

Shallow Subterranean Habitats (SSHs) are aphotic environments that are less than $10 \mathrm{~m}$ below the surface (Cul- ver \& Pipan 2008, 2011). They include hypotelminorheic and associated seepage springs, hyporheic, and epikarst

\footnotetext{
${ }^{1}$ Karst Research Institute ZRC SAZU, Titov trg 2, SI-6230 Postojna, Slovenia, e-mail: pipan@zrc-sazu.si

${ }^{2}$ Department of Environmental Science, American University, 4400 Massachusetts Ave. NW, Washington, DC 20016, USA, e-mail: dculver@american.edu

Received/Prejeto: 15.1.2013
} 
(defined below). SSHs, because of their close connections with the surface, are typically intermediate in environmental variability and in average parameter values between surface and deep subterranean habitats (Culver \& Pipan 2008, 2011). These patterns are largely based on extensive temperature records for both terrestrial (Pipan et al. 2011) and aquatic (Culver \& Pipan 2011) SSHs.

As a very general rule, productivity in surface terrestrial habitats is limited by availability of usable nitrogen (fixed nitrogen) and productivity in surface aquatic habitats is limited by availability of phosphorus. By contrast, productivity in deep subterranean habitats $(>10 \mathrm{~m}$ deep), especially cave streams (Simon \& Benfield 2002; Huntsman, Venarsky \& Bernstead 2011; Venarsky, Bernstead \& Huryn 2012), seems to be controlled by the amount of organic carbon, with "bottom-up" control of the detrititus-based community. Shallow subterranean habitats, with the exception of the hyporheic (see e.g. Danielopol et al. 2000; Datry et al. 2005; Marmonier et al. 2000; Vervier et al. 1992), have been little studied in this regard, and little is known about the amount of organic carbon available in SSHs.

In this study, we report on dissolved organic carbon values in a variety of SSHs present on Nanos Mountain and above nearby Postojna Planina Cave System in Slovenia. We compare these results with other studies of organic carbon in SSHs, and propose that organic carbon, especially dissolved organic carbon, is likely a limiting factor in many aquatic SSHs.

\section{A REVIEW OF AQUATIC SSHs}

Culver and Pipan (2011) propose that aquatic SSHs share the following features:

- groundwater-fed habitats less than $10 \mathrm{~m}$ from the surface;

- with many replicates across the landscape;

- rich in organic matter relative to other aquatic subterranean habitats;

- with intimate surface connections.

Portions of most caves are in the zone of less than $10 \mathrm{~m}$ from the surface, but the habitats typically extend deeper and so are not included. Exceptions are lava tubes which are always quite shallow (Palmer 2007), but lava tubes rarely have any water because of the high porosity of the lava in which they occur. The three major aquatic SSHs are (1) the hypotelminorheic and associated seepage springs, (2) epikarst, and (3) hyporheic flows associated with rivers and streams.

\section{HYPOTELMINORHEIC}

The Croatian speleobiologist, Milan Meštrov (1929-2010) applied the term "hypotelminorheic" to shallow groundwater habitats that are vertically isolated from the water table and are "constituted of humid soils in the mountains, rich in organic matter and traversed by moving water" (Meštrov 1962, 1964). He included cases where the habitat was in close proximity to caves (he gave an example from Moulis, France) and an example of where the outlet of a hypotelminorheic habitat was the beginning of a mountain stream in Risnjak, Croatia.

Elaborating on Meštrov's (1962) definition, Culver et al. (2006) proposed that the term "hypotelminorheic" be used to describe habitats with the following features (see also Culver \& Pipan 2008):

1. A perched aquifer fed by subsurface water that creates a persistent wet spot;

2. Underlain by a clay or other impermeable layer typically 5 to $50 \mathrm{~cm}$ below the ground surface;

3. Rich in organic matter compared with other aquatic subterranean habitats.

Culver et al. (2006) also indicated that the drainage area of a seepage spring is typically less than $1 \mathrm{ha}$, in a shallow depression, and that the leaves in the seepage spring are characteristically blackened and not skeletonized. Without a clay layer, water should tend to move vertically, and there would be no persistent water. Clay is a critical component of hypotelminorheic habitats, not only because it acts as a barrier to the downward movement of water, but also because during periods of drought, the water retained by the colloidal clay may serve as a refuge for invertebrates in the hypotelminorheic, into which they can burrow (Holsinger \& Dickson 1977). According to Ginet and Decu (1977), clay and its associated bacteria and organic matter may also have nutritional value for subterranean crustaceans. The water exits at a seepage spring, although there may not be flow at all times during the year.

For most species associated with the hypotelminorheic, it is the subterranean water of the hypotelminorheic and not the seepage spring, i.e., the groundwater/surface water ecotone (see Gibert 1991), that is their primary habitat. The seepage spring is the point of collecting most of the hypotelminorheic fauna, but is not the shallow groundwater habitat itself, but a few species are primar- 


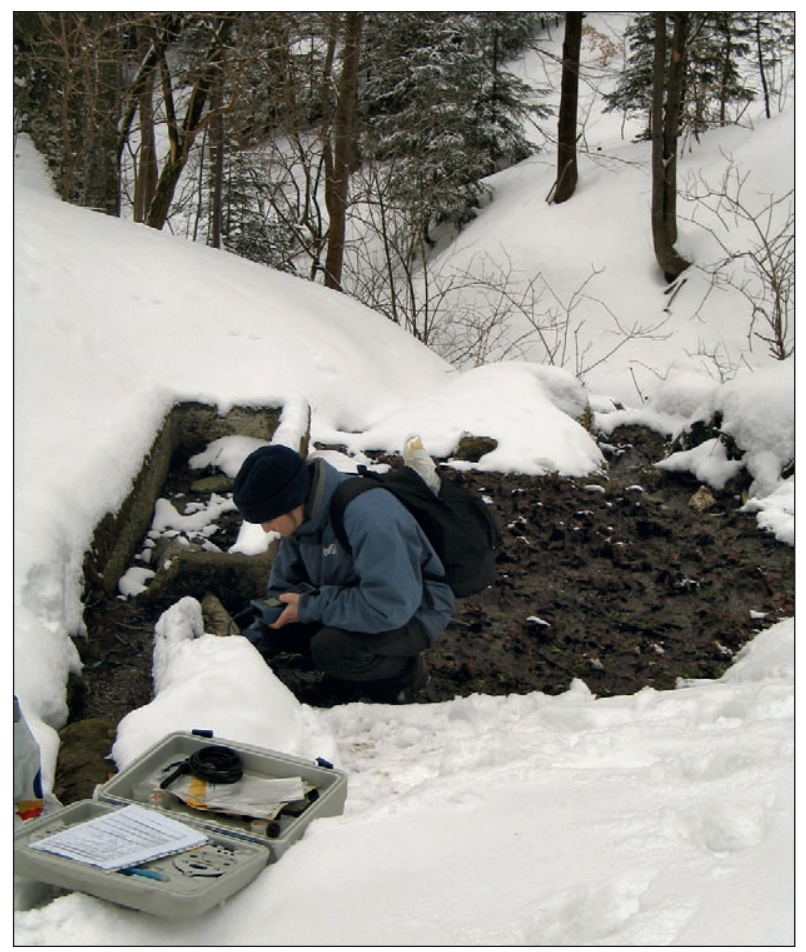

Fig. 1: Photographs of seepage springs: left-seepage spring at Medvenica Mountain, the site of the first description of the habitat by Meštrov (1962), photograph by D. Culver; right-seepage spring on Nanos Mountain, Slovenia, photograph by J. Mulec, used with permission; right-seepage spring in Scott Run Regional Park, Virginia, USA, photograph by W.K. Jones, used with permission.

ily inhabitants of the ecotone itself (see below). Many of the species found in the hypotelminorheic are hypotelminorheic specialists with the morphology typical of subterranean species, including loss of eyes and pigment and elongation of appendages (Culver \& Pipan 2011; Pipan \& Culver 2012). Micro-crustaceans are little studied in these habitats, but the macrofauna is dominated by amphipods (e.g. Culver, Holsinger \& Feller 2012). The hypotelminorheic and the associated seepage spring ecotone are clearly an example of a groundwater dependent ecosystem (Eamus \& Froend 2006). Seepage springs are also isolated wetlands, although a highly miniaturized ones. Photographs of several seepage springs are shown in Fig. 1.

\section{EPIKARST}

Epikarst is the uppermost part of karst, where stress release, climate, tree roots, and karst processes fracture and enlarge rock joints and cracks, creating a more porous zone over the carbonate rock in which only a few vertical joints and cracks occur (Bakalowicz 2012). This zone, the epikarst, is important as a site of cave formation, water storage, and a habitat for many species. Typically 3 to $10 \mathrm{~m}$ thick, epikarst overlies the water infiltration
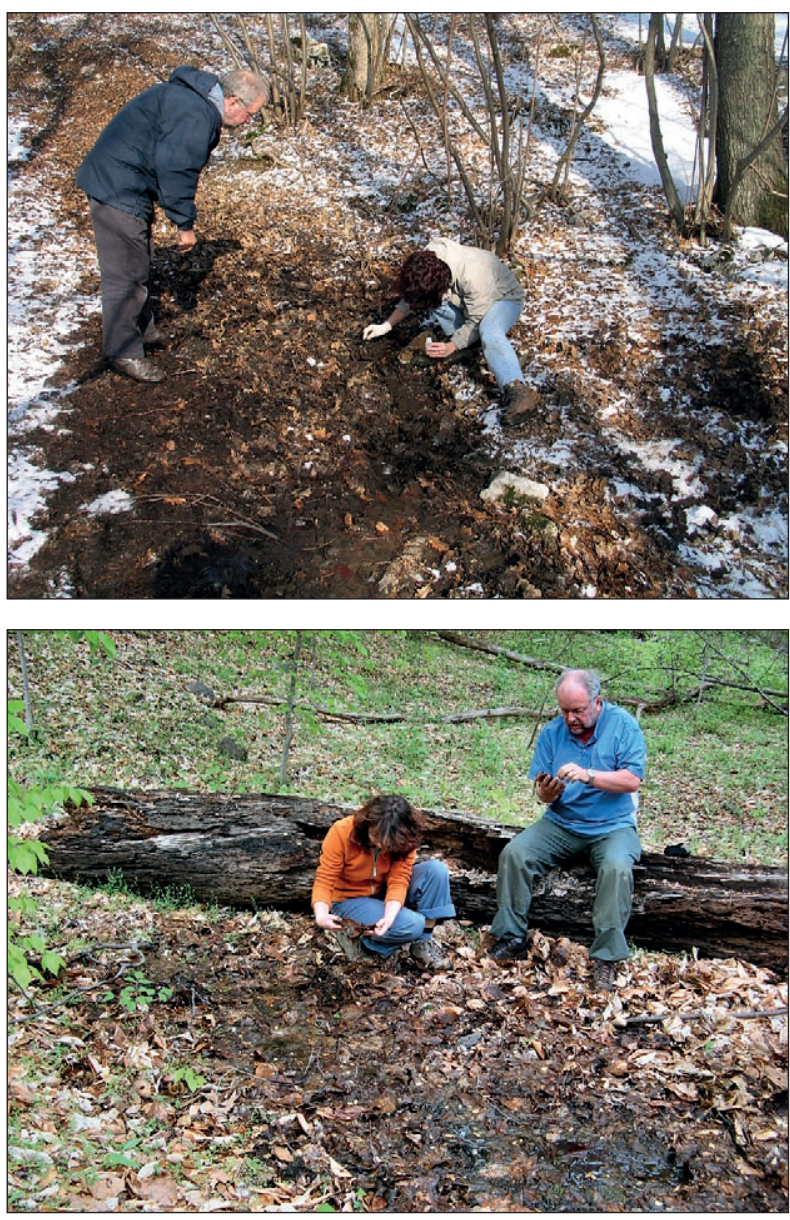

zone, which is itself intersected by occasionally enlarged vertical fractures and conduits (Fig. 2). Because of this, the base of the epikarst acts as an aquitard, a layer of low permeability, resulting in a local perched water table and a perched aquifer. According to Williams (2008) the typical porosity (per cent open space) of unweathered limestone is 2 percent while that of epikarst typically exceeds 20 percent. More generally, water storage in epikarst is the reason why cave streams typically have water for long periods of drought.

The connection of outflow from epikarst, which is measured by the output from drips in caves coming from epikarst, has a complex connection with precipitation Kogovšek (2010). Typically, output spikes after several precipitation events, which cumulatively fill the cavities in epikarst. Based on continuous monitoring of three epikarst drips for three years in Postojnska jama (Slovenia), Kogovšek (2010) was able to estimate total surface catchment area of an individual drip using precipitation and drip rate data. The largest catchment area of a drip was quite small, approximately $200 \mathrm{~m}^{2}$.

Epikarst harbors a rich aquatic fauna (Pipan 2005; Culver et al. 2012), much of it limited to subterranean 

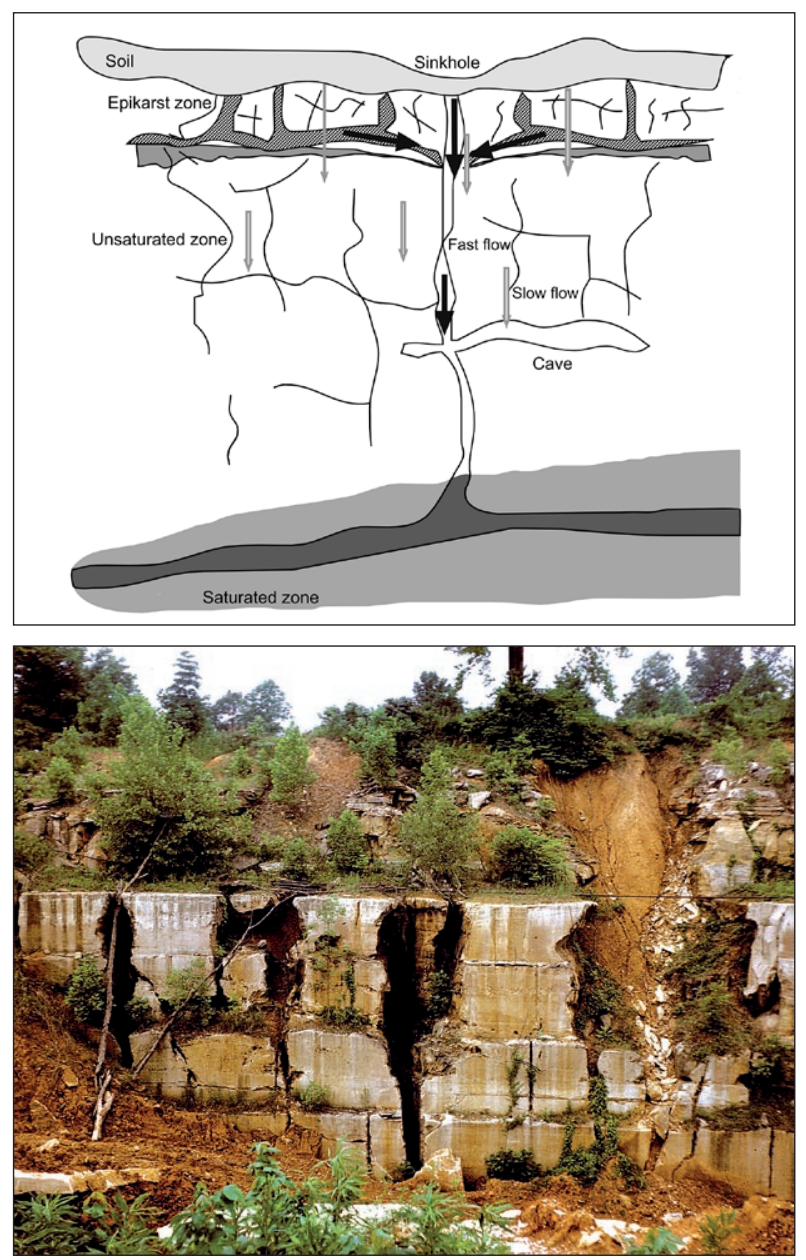

Fig. 2: Upper panel. Sketch of epikarst, from Pipan (2005), used with permission of ZRC Publishing. Lower panel. Photograph of exposed epikarst on the sawed face of a quarry in the Salem Limestone, Lawrence County, Indiana, USA. From Palmer (2004) and used with permission of the Karst Waters Institute.

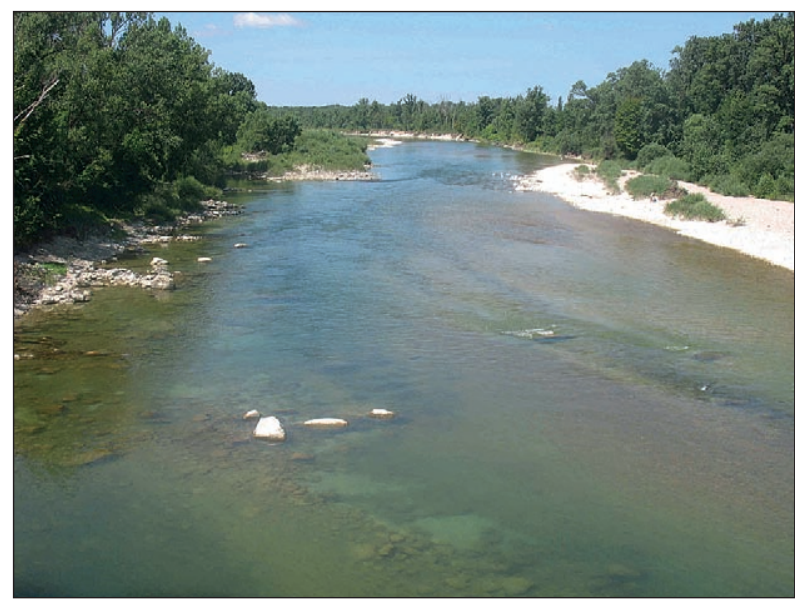

Fig. 3: The River Ain near its mouth on the Rhône River. It is a very species rich site and has numerous gravel bars and banks. Photograph by T. Pipan

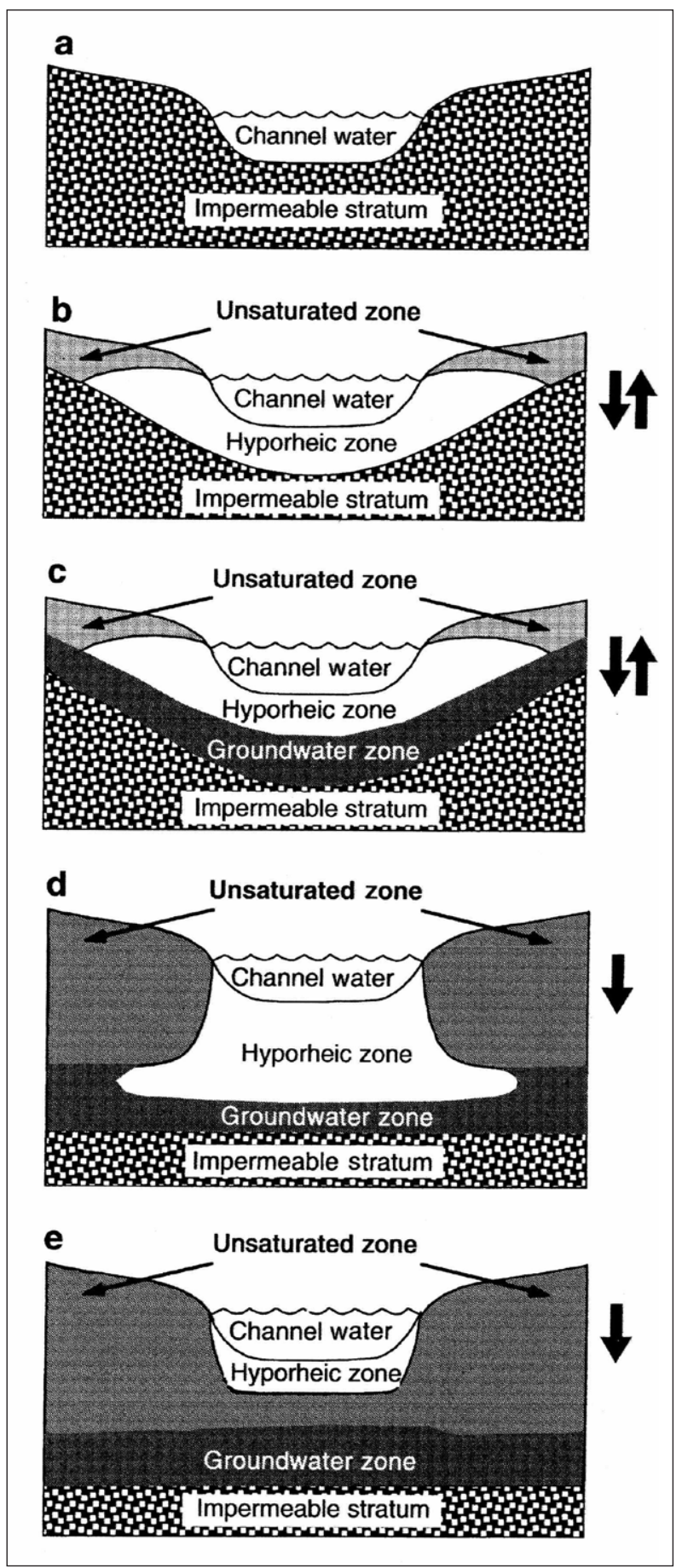

Fig. 4: Conceptual cross-sectional models of surface channels and beds showing relationships of channel water to hyporheic, ground water, and impermeable zones. Thick arrows indicate direction of water fluxes. (a) No hyporheic zone. (b) A hyporheic zone created only by advected channel water. (c) A hyporheic zone created by advection from both channel water and ground water. (d) A hyporheic zone created by infiltration of channel water beneath the stream bed (no parafluvial flow). (e) A perched hyporheic zone created only by infiltration of channel water beneath the stream bed. From Malard et al. (2002). 
habitats, and often limited just to epikarst habitats (Pipan \& Culver 2007). Numerically, the fauna is dominated by copepods and the macroscopic fauna is dominated by amphipods and isopods.

\section{HYPORHEIC}

The hyporheic zone, the best studied by far of all interstitial habitats, is the surface-subsurface hydrological exchange zone beneath and alongside the channels of rivers and streams. A more technical definition is provided by Krause et al. (2011):

A temporally and spatially dynamic saturated transition zone between surface and ground water bodies that derives its specific physical (e.g., water temperature) and biogeochemical (e.g., steep chemical gradients) characteristics from mixing of surface- and ground water to provide a dynamic habitat and potential refugia for obligate and facultative species.

The hyporheic of rivers is an ecotone between surface and groundwater (Fig. 3). The hyporheic zone may or may not have permanent groundwater (phreatic water) connections (Fig. 4). In rare cases, hyporheic and groundwater are absent, and the stream flows on imper- meable rock (Fig. 4a). In all other cases, there is water flow vertically and laterally from channel water and/or groundwater. When there are unconsolidated sediments along the stream bank, the hyporheic can extend tens of meters from the stream bank. One hyporheic type (Fig. 4e) is a rather curious one isolated from groundwater. On a small scale, it closely resembles the hypotelminorheic.

Transfers of matter and organisms through and into the hyporheic depend on the permeability of the substrate. If sediment load increases, fine particles can settle in the gravel bed reducing permeability, or slightly large particles can form a subsurface seal. In urban streams, such as Rock Creek in Washington, D.C., sediment load from storm water runoff is so heavy that nearly all pores of the hyporheic zone of some tributary streams are completely clogged and sealed (Culver \& Šereg 2004).

The hyporheic harbors a diverse and rich fauna, including subterranean species, species (typically Ephemeroptera and Plecoptera) that spend most of their lives in the hyportheic except for a brief period as winged adults (Gibert et al. 1994), and species also found in streams and rivers.

\section{METHODS AND MATERIALS}

\section{STUDY SITES}

Nanos is largely flysch mountain in the Kras (Karst in English) region of Slovenia. It ranges in elevation from $1262 \mathrm{~m}$ at the summit to approximately $550 \mathrm{~m}$ at its base near the village of Razdrto. On the southern flank of the mountain, near Razdrto, we located a series of three seepage springs, one small stream with a hyporheic zone, two small springs (both gushets sensu Krešič 2010) near the headwaters of a stream, and a small surface stream. Seepage springs were separated into two groups-those that contained amphipods of the genus Niphargus, a common inhabitant of European groundwater and those that lack this amphipod genus. These sites were within $600 \mathrm{~m}$ of each other and ranged in ele- vation from 600 to $750 \mathrm{~m}$. Samples were taken monthly during 2011.

\section{SAMPLE ANALYSIS}

Water was collected in a $60 \mathrm{cc}$ syringe and passed through a $0.45 \mathrm{~mm}$ glass fiber filter (Gelman GF/F). Water samples were filtered into an acid washed $50 \mathrm{~mL}$ HDPE sample bottle and preserved to $\mathrm{pH} 2$ with two drops of concentrated $\mathrm{HCl}$. The samples were analyzed for dissolved organic carbon (DOC) by concentration using the persulfate digestion method on a Thermo Scientific HiPerTOC Analyzer. Each sample was analyzed five times, and the mean value of these is what is reported. Statistical differences were analyzed using ANOVA.

\section{RESULTS}

Estimates of dissolved organic carbon are shown in detail in Tab. 1 and summarized in Fig. 5. There were no statistically significant differences among the sites (ANOVA), in part because of small sample sizes, but especially because of the large range of values for DOC found at each site. Except for one seepage spring, the range of values was more than 2.5 times the median. Activities of medium to large mammals (e.g. feeding and defecation) is a possible 
Tab. 1: Mean values ( \pm Standard Error) of dissolved organic carbon from a series of habitats on Nanos Mountain, Slovenia. Each value is based on five analyses of a single water sample.

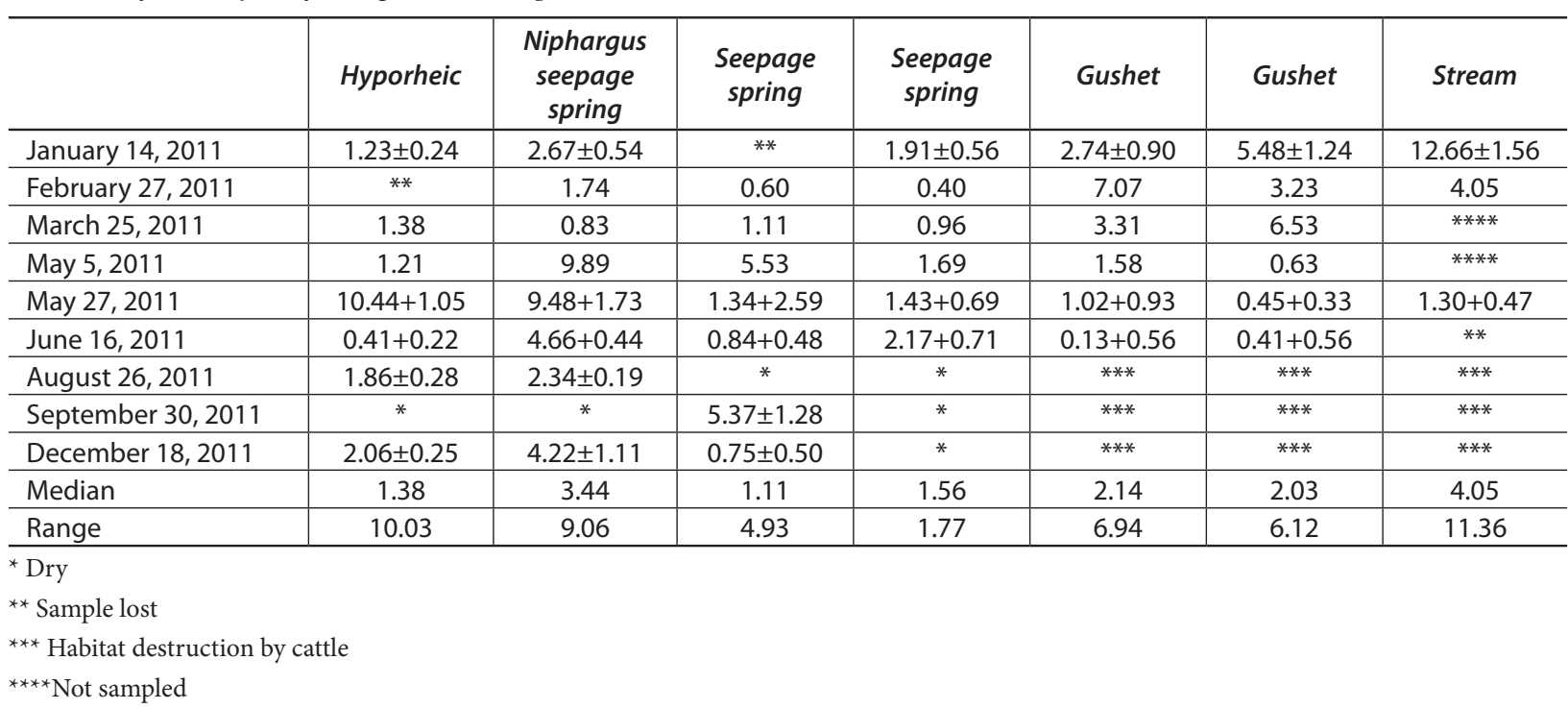

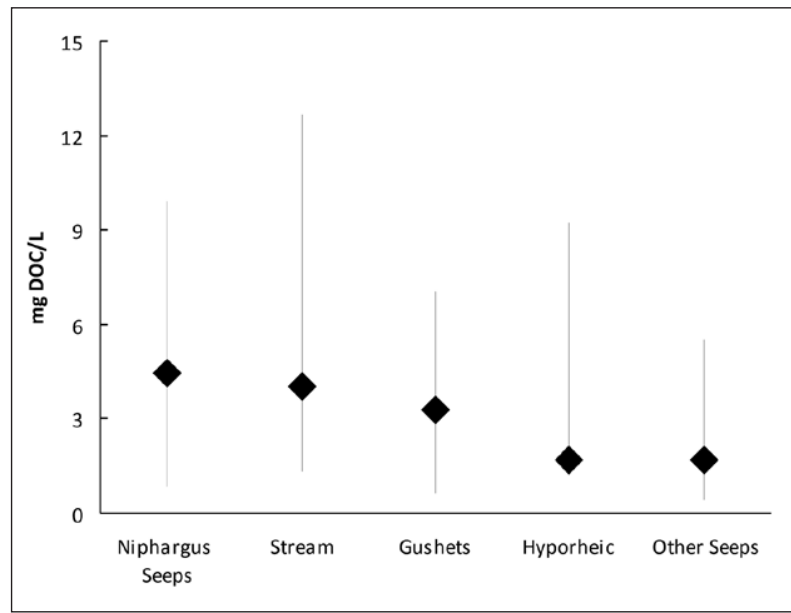

explanation for this high variability. The non-significant differences in median values showed some interesting patterns. First, typical values for DOC in seepage springs range between 1 and $3.5 \mathrm{mg} \mathrm{L}^{-1}$ (Tab. 1). Second, DOC was higher in the seepage spring with Niphargus amphipods than in seepage springs without macroscopic stygobionts such as Niphargus.

Fig. 5: Medians, maxima, and minima of dissolved organic carbon in $\mathrm{mg} \mathrm{L}^{-1}$ for the five habitats measured on Nanos Mountain, Slovenia, listed in order of decreasing median DOC: seepage springs with the stygobiotic amphipod genus Niphargus, surface stream, gushets, hyporheic, and seepage springs without Niphargus.

\section{DISCUSSION}

Fong and Kavanaugh (2010) suggest that the hypotelminorheic amphipod Stygobromus tenuis potomacus actively foraged in a seepage spring, and our results support his conjecture. The higher DOC levels in one seepage spring may tend to concentrate Niphargus near the seepage spring. Third, the absence of significant differences among sites indicates the superfical nature all of the subterranean habitats have in common. The absence of differences also suggests that there is not significant reduction of organic carbon levels by the consumer communities in the different habitats.
Overall, dissolved organic carbon at the boundary of the hypotelminorheic (i.e. the seepage spring) had a median value of approximately $1.4 \mathrm{mg} \mathrm{C} \mathrm{L}^{-1}$ when no macroscopic stygobionts were present and approximately $3.4 \mathrm{mg} \mathrm{C} \mathrm{L}^{-1}$ when they were (Tab. 1). Furthermore, these values were not very different from that of a nearby

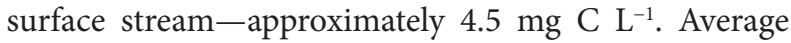
values are not very different from those observed for the hyporheic, an example of which is shown in Tab. 2. In this study, Marmonier et al. (2000) found mean values for DOC ranging from 1.9 to $3.5 \mathrm{mg} \mathrm{C} \mathrm{L}^{-1}$, very similar 
to the median values found in the Slovenian hypotelminorheic sites. Other studies, such as that of Datry et al. (2005) found that there was a sharp decline in organic carbon with depth, if measurements were made over a greater depth range. In general, it would appear that organic carbon values within $50 \mathrm{~cm}$ of the surface are usually not very different.

Tab. 2: Dissolved Organic carbon (DOC) component of interstitial water at two hyporheic sties in the Rhône River basin in France. At the Grand Gravier section of the Rhône River, 12 samples were taken from depths of 20,50, and $100 \mathrm{~cm}$. Modified from Marmonier et al. (2000).

\begin{tabular}{llcc}
\hline & Habitat & $\begin{array}{c}m g C L^{-1} \pm \\
\text { S.E. }\end{array}$ & $n$ \\
\hline Vanoise Brook & Surface & $1.5 \pm 0.2$ & 6 \\
& $40 \mathrm{~cm}$ deep in channel & $1.9 \pm 0.1$ & 6 \\
& $40 \mathrm{~cm}$ deep in gravel bar & $1.8 \pm 0.3$ & 6 \\
Grand Gravier & $1.5 \mathrm{~m}$ in river channel & $3.5 \pm 0.3$ & 12 \\
& shore & $3.2 \pm 0.3$ & 12 \\
& $1.5 \mathrm{~m}$ on bank & $2.8+0.2$ & 12 \\
\hline
\end{tabular}

What is different between hyporheic and hypotelminorheic sites is their temporal and spatial variability. DOC values in the study of Marmonier et al. (2000) had small standard errors, while DOC values in the hypotelminorheic varied widely (Fig. 5). For carbon entering the hyporheic at sink points, there is a dilution and mixing effect that would act to reduce local differences. The same is not the case for the hypotelminorheic, where inputs such as animal waste or decaying biomass, would not be diluted or homogenized because there is very little surface water, and the vertical and horizontal distance the water moves into the ground is very small.

The third shallow subterranean habitat-epikarstpresents a contrast with the hyporheic and hypotelminorheic with respect to the pattern of dissolved organic carbon. There are also more extensive data on DOC in epikarst than for the other two SSHs. All of these studies measure water dripping out of epikarst habitats into caves since this is the only point of access to the water. Thus, DOC is measured at the exit of water from the epikarst.

The most extensive study is that of Ban et al. (2008). They did an extensive series of temporal and spatial measurements of organic carbon in three drips between 70 $\mathrm{m}$ and $100 \mathrm{~m}$ apart in Shihua Cave, China. The temporal pattern of dissolved organic carbon (DOC) is shown in Fig. 6. The general shape of the pattern is the same for all three drips, but the amount of DOC also varies from drip to drip. The highest DOC value was observed in drip JG, with a value of $2.76 \mathrm{mg} \mathrm{L}^{-1}$. Mean values ranged from $1.06 \mathrm{mg} \mathrm{L}^{-1}$ at JG to $0.73 \mathrm{mg} \mathrm{L}^{-1}$ at PL, generally lower than values found in the hypotelminorheic (Fig. 5) and hyporheic (Tab. 2). Spikes in DOC, which were somewhat less extreme than those observed for the hypotelminorheic, corresponded to precipitation events (e.g. early August 2004). Ban et al. (2008) suggest that more DOC is lost from either longer flow paths or longer times.

DOC analyses by Simon, Pipan, and Culver (2007) of Organ Cave, West Virginia, USA, and Postojna Planina Cave System in Slovenia allow comparison of DOC levels in epikarst with other components of cave and karst system. As was the case with Shihua Cave (Ban et al. 2008), DOC levels in epikarst waters were typically around $1.0 \mathrm{mg} \mathrm{L}^{-1}$, or even lower, in the case of Postojna Planina Cave System (Tab. 3). In Postojna Planina Cave System, but not in Organ Cave, cave streams had more organic matter than epikarst drips. However, DOC from

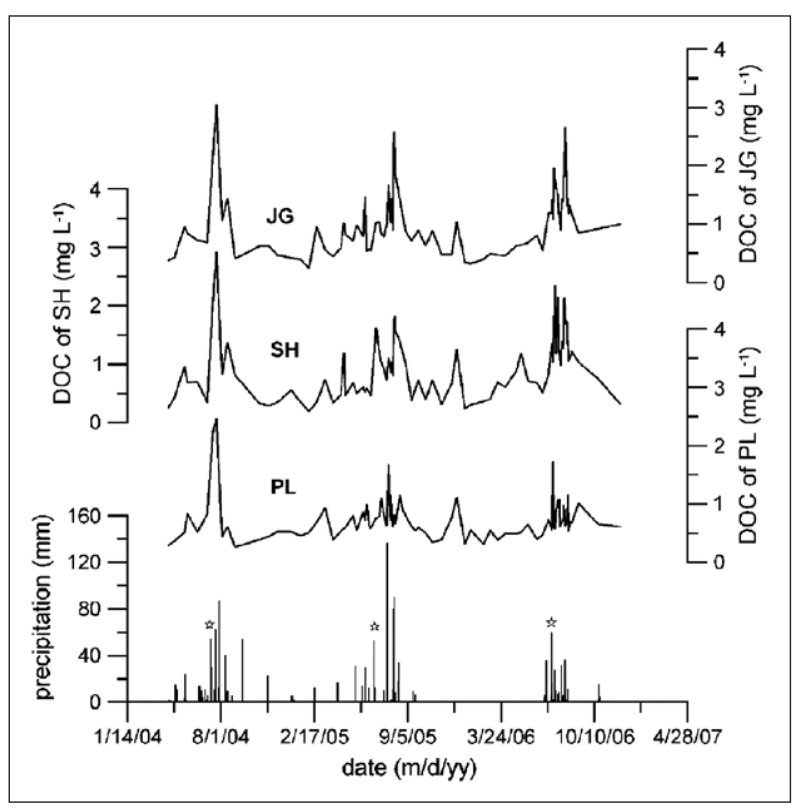

Fig. 6: Rainfall amount and intra- and inter-annual variation of DOC in three drip sites at Shihua Cave during the period between April 2003 and December 2006. The important rainfall events causing the increase in DOC concentration in drip water are marked with hollow stars. From Ban et al. (2008).

epikarst water is likely very important in both caves, both because it is more ubiquitous than cave streams, and because the organic carbon in epikarst water is more metabolically accessible than that in cave streams. An example is shown in Fig. 7, where DOC quantity and quality are compared for Postojna Planina Cave System. Simon et al. (2010) measured specific UV absorbance (SUVA) at $254 \mathrm{~nm}$, a standard measure of the frequency of aromatic compounds. Higher SUVA values tend to mean the compounds are less reactive and less easy to metabolize but there are numerous caveats (Wesihaar et al. 2003). SUVA 
Tab. 3: Dissolved organic carbon ( \pm Standard Error) for Organ Cave, West Virginia, USA, and Postojna Planina Cave System, Slovenia. From Simon et al. (2007).

\begin{tabular}{lcc|cc}
\hline \multicolumn{2}{c}{ Organ Cave } & \multicolumn{2}{c}{ Postojna Planina Cave System } \\
\hline Habitat & DOC $\left(\mathrm{mg} \mathrm{L}^{-1}\right)$ & $\mathrm{n}$ & $\mathrm{DOC}\left(\mathrm{mg} \mathrm{L}^{-1}\right)$ & $\mathrm{n}$ \\
\hline Sinking Streams & $7.67 \pm 1.03$ & 3 & $4.36 \pm 0.46$ & 2 \\
Epikarst Drips & $1.10 \pm 0.15$ & 20 & $0.70 \pm 0.04$ & 99 \\
Cave Streams & $1.08 \pm 0.32$ & 6 & $4.75 \pm 1.57$ & 3 \\
Resurgence & $0.90 \pm 0.17$ & 3 & $2.67 \pm 0.80$ & 2 \\
\hline
\end{tabular}

values, as well as several other measures of reactivity, all suggest that organic carbon in epikarst water is more accessible to the subterranean community than cave stream water. Clearly this is a topic worthy of more research.
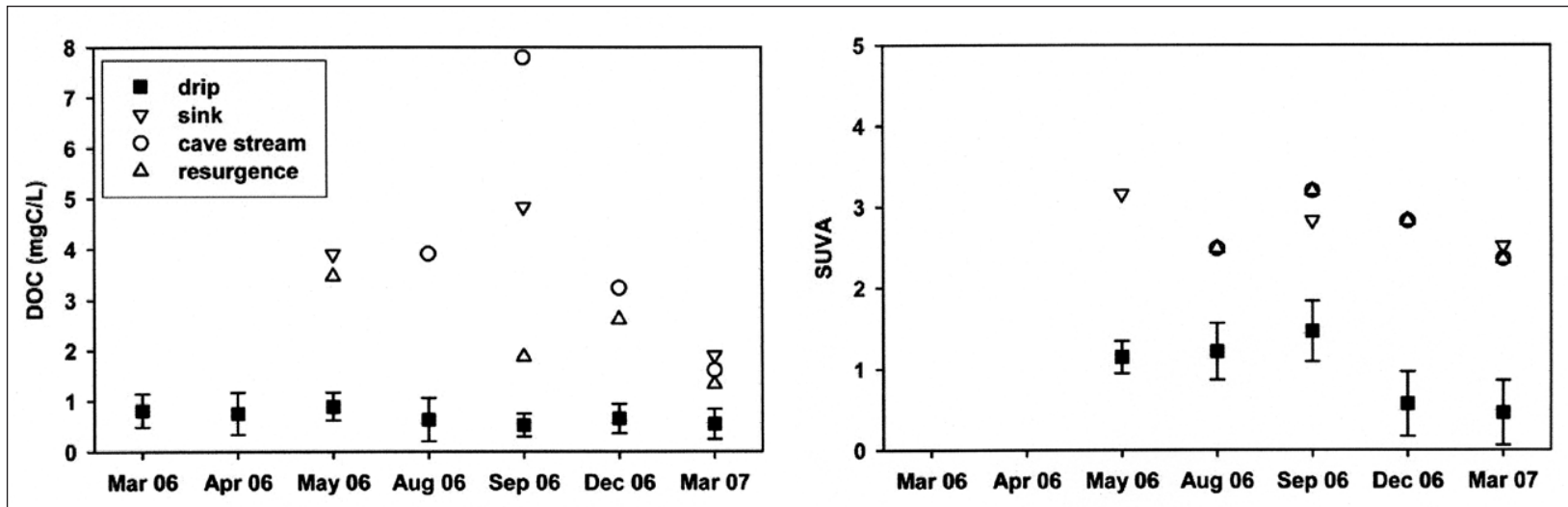

Fig. 7: Comparison of amounts of DOC (left panel) and specific UV absorbance at $254 \mathrm{~nm}$ (right panel) for a series of habitats in Postojna Planina Cave System, Slovenia. Modified from Simon et al. (2010).

\section{CONCLUSIONS}

Water in the three major shallow subterranean habitats differs in the amount and variability of dissolved organic carbon. The hypotelminorheic, the most superficial of the three and one with close surface connections, has levels of dissolved organic carbon typical of surface waters in the immediate vicinity, between 1 and $4 \mathrm{mg} \mathrm{L}^{-1}$ in the $\mathrm{Na}$ nos Mountain study area. There was very high temporal variability with occasional spikes of $10 \mathrm{mg} \mathrm{L}^{-1}$ or more, reflecting the poorly integrated nature of the system. The hyporheic, which is also closely connected with the surface, had similar values of DOC, but with less variability, reflecting the well connected and integrated nature of this habitat. Finally, epikarst showed the lowest average values, with spikes associated with precipitation events. Preliminary analysis of organic carbon quality suggests that epikarst water is more accessible to the subterranean community than cave stream water.

\section{REFERENCES}

Bakalowicz, M., 2012: Epikarst.- In: White, W.B. \& D.C. Culver (eds.) Encyclopedia of caves, second edition. Elsevier Press, pp. 284-288, Amsterdam, The Netherlands.
Ban, R., Pan, G., Zhu, J., Cai, B. \& M. Tan, 2008: Temporal and spatial variations in the discharge and dissolved organic carbon of drip waters in Beijing Shihua Cave, China.- Hydrological Processes, 22, 3749-3758. 
Culver, D.C. \& T. Pipan, 2008: Superficial subterranean habitats - gateway to the subterranean realm?. Cave and Karst Science, 35, 5-12.

Culver, D.C. \& T. Pipan, 2011: Redefining the extent of the aquatic subterranean biotope - shallow subterranean habitats.- Ecohydrology, 4, 721-730.

Culver, D.C., Pipan, T. \& S. Gottstein, 2006: Hypotelminorheic-a unqiue freshwater habitat.- Subterranean Biology, 4, 1-8.

Culver, D.C., Holsinger, J.R. \& D.J. Feller, 2012: The fauna of seepage springs and other shallow subterranean habitats in the mid-Atlantic Piedmont and Coastal Plain.- Northeastern Naturalist Memoirs, 19 (Monograph 9), 1-42.

Culver, D.C. \& I. Šereg, 2004: Kenk's Amphipod (Stygobromus kenki) and other amphipods in Rock Creek Park, Washington, D.C.- Report to Rock Creek Park, National Park Service, Washington, DC. USA.

Datry, T., Malard, F. \& J. Gibert, 2005: Response of invertebrate assemblages to increased groundwater recharge rates in a phreatic aquifer.- Journal of the North American Benthological Society, 24, 461-477.

Danielopol, D.L., Pospisil, P., Dreher, J., Mösslacher, F., Torreiter, P., Geiger-Kaiser, M. \& A. Gunatilaka, 2000: A groundwater ecosystem in the Danube wetlands at Wien (Austria).- In: Wilkens, H., Culver, D.C. \& W.F. Humphreys (eds.) Subterranean ecosystems. Elsevier Press, pp. 481-511, Amsterdam, The Netherlands.

Eamus, D. \& R. Froend, 2006: Groundwater-dependent ecosystems.- Australian Journal of Botany, 54, 91-237.

Fong, D.W. \& K.E. Kavanaugh, 2010: Population dynamics of the stygobiotic amphipod crustacean Stygobromus tenuis potomacus and isopod crustacean Caecidotea kenki at a single hypotelminorheic habitat over a two-year span.- In: Moškrič, A. \& P. Trontelj (eds.) ICSB International Conference on Subterranean Biology, 2010 Abstract Book, 22-23, Postojna, Slovenia.

Gibert, J., 1991: Groundwater systems and their boundaries: conceptual framework and prospects in groundwater ecology.- Verhaltlungen der Internationalen Vereinigung für Theoretische und Angewandte Limnologie, 24, 1605-1608.

Gibert, J., Stanford, J.A., Dole-Olivier, M.-J. \& J.V. Ward, 1994: Basic attributes of groundwater ecosystems and prospects for research.- In: Gibert, J., Danielopol, D.L. \& J.A. Stanford (eds.) Groundwater ecology. Academic Press, pp. 7-40, San Diego, CA.
Ginet, R. \& V. Decu, 1977: Initiation à la biologie a l'écologie souterraines.- J-P Delarge, Paris.

Holsinger, J.R. \& G.W. Dickson, 1977: Burrowing as a means of survival in the troglobitic amphipod crustacean Crangonyx antennatus Packard (Crangonyctidae).- Hydrobiologia, 54, 195-199.

Huntsman, B.M., Venarsky, M.D. \& J.P. Bernstead, 2011: Relating carrion breakdown rates to ambient resource level and community structure in four cave stream ecosystems.- Journal of the North American Benthological Society, 30, 882-892.

Kogovšek, J., 2010: Characteristics of percolation through the karst vadose zone.- ZRC Publishing, Ljubljana, Slovenia.

Krause, S., Hannah, D.M., Fleckenstein, J.H., Heppell, C.M., Kaeser, D., Pickup, R., Pinay, G., Robertson, A.L. \& P.J. Wood, 2011: Inter-disciplinary perspectives on processes in the hyporheic zone.- Ecohydrology, 4, 481-499.

Krešič, N., 2010: Types and classifications of springs.- In: Kresic, N. \& Z Stevanovic (eds.) Groundwater hydrology of springs. Engineering, theory, management, and sustainability. Elsevier Press, pp. 31-86, Amsterdam, The Netherlands.

Malard, F., Tockner, K., Dole-Oliver, M.-J. \& J.V. Ward, 2002: A landscape perspective of surface-subsurface hydrological exchange in river corridors.- Freshwater Biology, 47, 621-640.

Marmonier, P., Creuzé des Châtelliers, M., Dole-Olivier, M.-J., Plénet, S. \& J. Gibert, 2000: Rhône groundwater systems.- In: Wilkens, H., Culver, D.C. \& W.F. Humphreys (eds.) Subterranean ecosystems. Elsevier Press, pp. 513-531, Amsterdam, The Netherlands.

Meštrov, M., 1962: Un nouveau milieu aquatique souterrain: le biotope hypotelminorheique.- Compte Rendus de l'Académie des Sciences, Paris, 254, 2677-2679.

Meštrov, M., 1964: Différences et relations faunistiques et écologiques entre les milieu souterrains aquatiques.- Spelunca Mémoires, 4, 185-187.

Palmer, A.N., 2007: Cave geology.- Cave Books, Dayton, Ohio.

Pipan, T., 2005: Epikarst - a promising habitat.- Založba ZRC, Ljubljana, Slovenia.

Pipan, T. \& D.C. Culver, 2007: Regional species richness in an obligate subterranean dwelling faunaepikarst copepods.- Journal of Biogeography, 34, 854-861.

Pipan, T., López, H., Oromí, P., Polak, S. \& D.C. Culver, 2011: Temperature variation and the presence of troglobionts in terrestrial shallow subterranean habitats.- Journal of Natural History, 45, 253-273. 
Pipan, T. \& D.C. Culver, 2012: Convergence and divergence in the subterranean realm: a reassessment. Biological Journal of the Linnean Society, 107, $1-14$.

Simon, K.S. \& E.F. Benfield, 2002: Ammonium retention and whole-stream metabolism in cave streams.Hydrobiologia, 482, 31-39.

Simon, K.S., Pipan, T. \& D.C. Culver, 2007: A conceptual model of the flow and distribution of organic carbon in caves.- Journal of Cave and Karst Studies, 69, 279-284.

Simon, K.S., Pipan, T., Ohno, T. \& D.C. Culver, 2010: Spatial and temporal patterns in abundance and character of dissolved organic matter in two karst aquifers.- Fundamental and Applied Limnology, $177,81-92$.
Venarsky, M.D., Bernstead, J.P. \& A.D. Huryn, 2012: Effects of organic matter and season on leaf litter colonization and breakdown in cave streams.- Fresh Water Biology, 57, 773-786.

Vervier, P., Gibert, J., Marmonier, P. \& M.-J. Dole-Olivier, 1992: A perspective on the permeability of the surface freshwater-groundwater ecotone.- Journal of the North American Benthological Society, 11, 93-102.

Weishaar, J. L., Aiken, G. R., Bergamaschi, B. A., Fram, M. S., Fujii, R. \& K. Mopper, 2003: Evaluation of specific ultraviolet absorbance as an indicator of the chemical composition and reactivity of dissolved organic carbon.- Environmental Science and Technology, 37, 4702-4708.

Williams, P.W., 2008: The role of the epikarst in karst and cave hydrogeology: a review.- International Journal of Speleology, 37, 1-10. 